\title{
Status of the Ivory-billed Woodpecker Campephilus principalis in Cuba: almost certainly extinct
}

\author{
MARTJAN LAMMERTINK and ALBERTO R. ESTRADA
}

\section{Summary}

The Ivory-billed Woodpecker Campephilus principalis has suffered from destruction of its habitat over the whole of its range, being last recorded in eastern Cuba (Ojito de Agua) in 1987. The only chance for the species was that the last-known birds had moved to adjacent areas, or that other populations existed in other mountain ranges. Between February and May 1993 an extensive search for the species and for suitable habitat was carried out in mountain areas of eastern Cuba. In the surroundings of Ojito de Agua no suitable large old-growth forests remain, and evidence for the absence of Ivory-billed Woodpeckers from the area is discussed. In the region surveyed, only around Pico la Bayamesa in the Sierra Maestra does an almost untouched forest still stand, but this is probably outside the species's original range. Ojito de Agua and Pico la Bayamesa should nevertheless be fully protected. The last known population of Ivory-billed Woodpecker appears to have become extinct in 1989 or 1990. Scaling of bark from dead pines, formerly considered a sure sign of the species's presence, may be caused by weather damage.

El hábitat del Carpintero Real Campephilus principalis sufrió una sostenida destrucción a través de toda su distribución. Esta especie fue reportada por última vez en el este de Cuba (Ojito de Agua) en 1987. La última oportunidad para la especie radicaba en que los últimos carpinteros vistos se desplazaran hacia áreas adyacentes o que diferentes poblaciones vivieran aisladas en otras regiones montañosas. Entre Febrero y Mayo de 1993 se realizó una búsqueda intensa, tanto por reportes del ave como por hábitats apropiadas para la misma en zonas montañosas del este de Cuba. En los alrededores de Ojito de Agua no existen bosques viejos donde estas aves puedan encontrar refugio. Indicios de la ausencia del Carpintero Real en Ojito de Agua son discutidos. No fue encontrada otra área montañosa con hábitat apropiado para la especie. Solamente en los alrededores del Pico la Bayamesa en la Sierra Maestra aún queda una zona boscosa casi intacta, pero esta área probablemente se encuantra fuera de la distribución original del Carpintero Real. No obstante, Ojito de Agua y Pico la Bayamesa deben ser completamente protegidos. Probablemente la última población conocida del Carpintero Real se extinguió entre 1989 y 1990. La descamación de la corteza de los pinos muertos, primariamente considerada como una prueba segura de la presencia de la especie, puede también ser causada por factores climáticos. 


\section{Introduction}

Since the publication of an excellent monograph (Tanner 1942) on the Ivorybilled Woodpecker Campephilus principalis, the species has been one of the world's best-known threatened birds. That study pointed out its specialized foraging technique, which involved scaling bark from dead trees in order to search for wood-boring beetle larvae. To find sufficient food one pair needed at least $16 \mathrm{~km}^{2}$ of pristine bottomland forest. In 1939, an estimated 22 birds lived in the last remnants of this habitat in the southern U.S.A. (Tanner 1942). Unfortunately, logging continued in most of these areas, and as a consequence the last accepted sightings of Ivory-billed Woodpecker in the U.S.A. were in the 1950s (Short and Horne 1990), although Dennis (1979) considers sightings in modified forests up to the late 1970 s to have been possibly correct. Originally, the distribution had extended from south-east Carolina, southern Kentucky, Illinois, Missouri, Arkansas and Oklahoma to the coast of the Gulf of Mexico and Florida in the U.S.A., and throughout the island of Cuba (Collar et al. 1992).

In Cuba, the species originally frequented lowland hardwood forest as well as pine forest in hilly country (Lamb 1957). By the beginning of the twentieth century the lowland forests were cut over and the bird became confined to mountain areas in eastern Cuba (a complete review of records is in Collar et al. 1992). As a result of studies in 1948 and 1956 (observations, or information from local guides) six apparently occupied sites were located in the hills south of Moa (Dennis 1948, Lamb 1957), and there were reports there again in the 1960s and 1970s. Searches in this area were begun again in 1985 (Short 1985, Estrada and Alayón 1986a), and in March 1986 A.R.E. and G. Alayón found a female in a pine forest called Ojito de Agua (Estrada and Alayón 1986b). This is one of the furthest inland territories described by Lamb. At the same spot a male and female were observed by an international team in April 1986 (Short and Horne 1986), and the last positive sighting, there or anywhere, was made by G. Alayón and A. Posada on 16 March 1987, with a possible glimpse in March 1988 (Jackson 1991), and another, even less certain, in Sierra de Moa during April 1991 (Collar et al. 1992).

During January-May 1991, M.L. spent a total of 62 days in Ojito de Agua and surroundings. No Ivory-billed Woodpeckers were seen or heard and no fresh signs of bark-scaling activity were found. Furthermore, the forest of Ojito de Agua appeared not to be optimal habitat for the species since the best parts were cut over in the 1950 s and 1980 and are now poor secondary forest. Eight kilometres to the north-east an area was found where in the mid-1980s suitable forest was logged. It is quite possible that the birds found in 1986 and 1987 came from this logged forest and could live only temporarily in the poor forest of Ojito de Agua. At short distances east and west of Ojito de Agua old-growth forest was found to which the birds could have retreated if the suitable habitat extended far enough (Lammertink 1992). McNeely (1992) affirmed the good condition of the forest east of Ojito de Agua. A second expedition thus seemed to be required in order to search these areas more extensively. Furthermore, other mountain ranges - whether or not they were previously known to harbour Ivory-billed Woodpeckers needed to be explored for possible additional populations. 


\section{The 1993 search}

\section{Methods}

From 17 February to 31 March 1993 the authors, cooperating with Huub Huneker, Carlos Peña Rodríguez and Uilder Azhárez Pérez, searched Ojito de Agua and adjacent areas for Ivory-billed Woodpeckers and for suitable forest for the species. Frequently the "kent" call (Tanner 1942) of the Ivorybilled Woodpecker was imitated with the mouthpiece of a trumpet (after a recording by Allen and Kellogg, in Reynard 1988) to see if it would raise a response. For 23 days during daylight hours a group of dead pine trees Pinus cubensis was observed that appeared to have feeding signs of an Ivory-billed Woodpecker. From 15 April to 4 May the authors visited other mountain areas in eastern Cuba to assess the suitability of the forests there.

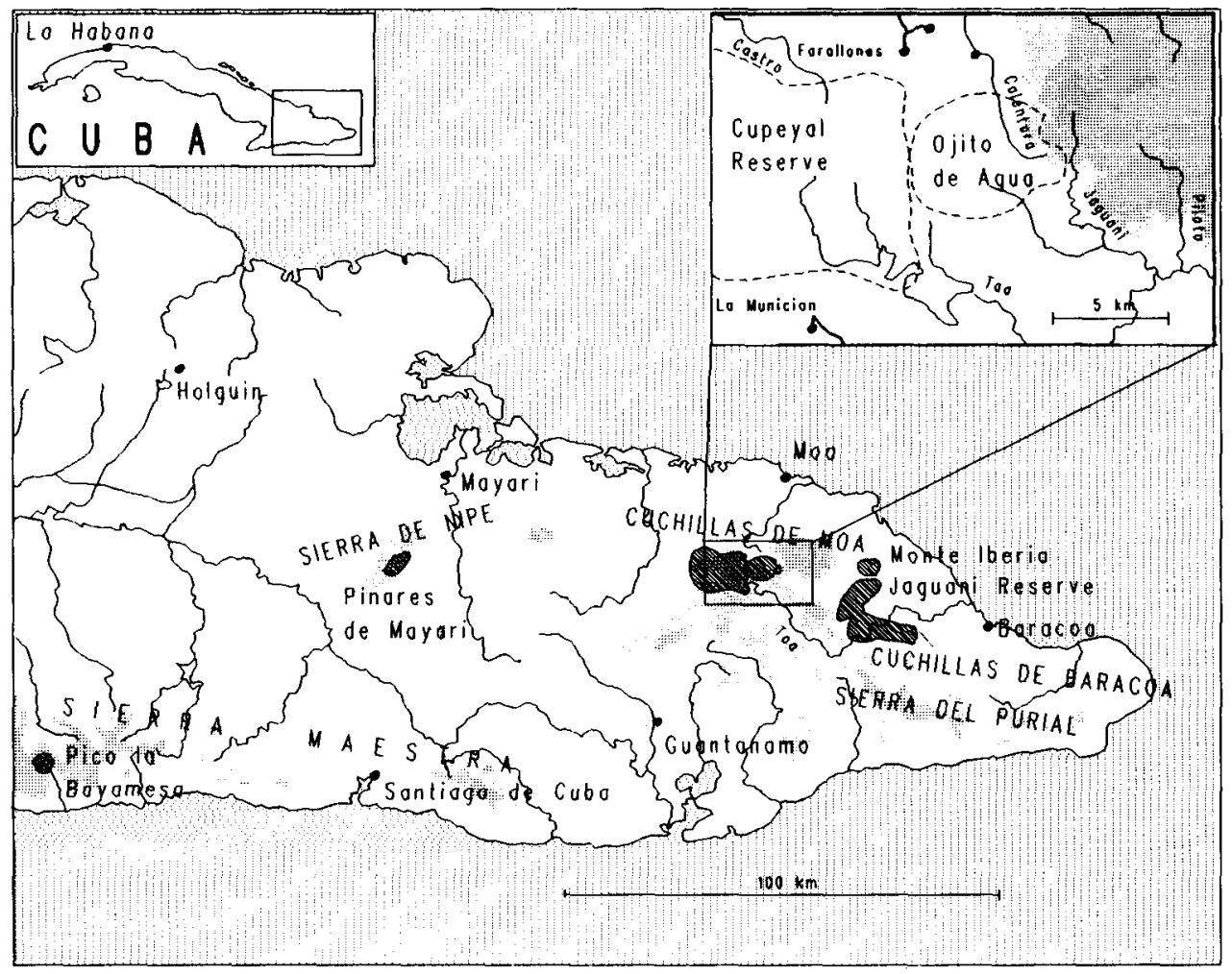

Figure 1. Study areas in eastern Cuba

West and east of Ojito de Agua

Most of the area which is now the Cupeyal Reserve, west of Ojito de Agua, was clear-cut in the 1950s. In one of the old-growth patches located in 1991, 
a $2-\mathrm{km}^{2}$ fragment of primeval hardwood forest left in a canyon bordering the pine forest of Ojito de Agua, we found an old hole presumed to be that of an Ivory-billed Woodpecker. No new holes were found, however, and a row of dead pines nearby appeared not to have been used for foraging. Around the headwaters of the Castro river about $4 \mathrm{~km}^{2}$ of old-growth hardwood forest was found to remain. This area is isolated by poor regenerating forest from the main forest of Ojito de Agua, and no signs of Ivory-billed Woodpeckers were found there. Along the western tributary of the Toa river $8 \mathrm{~km}^{2}$ of mature pine forest was logged in 1992, and an Ivory-billed Woodpecker had been reported there in 1984 (Short 1985).

East of Ojito de Agua untouched forest remains only in the steep valleys of the headwaters of the Jaguaní and Piloto rivers. Because of the steep slopes, however, most of the soil has been washed away and few large trees grow there. These areas would probably be unable to support an Ivory-billed Woodpecker.

\section{Indications of presence and absence of birds}

In the centre of Ojito de Agua, on the upper reaches of the Calentura river, a few dead pines Pinus cubensis were found which had bark missing at various places, the orange colour of the wood underneath indicating that the bark had scaled off recently. For A.R.E., who saw the workings of many Ivory-billed Woodpeckers in 1986, it looked like an authentic feeding sign of the bird. During our 23 days of observation no Ivory-billed Woodpecker appeared at these dead pines, but following 48 hours of heavy rainstorms and then two hot and sunny days more bark had fallen off. Thus it seems that the weather can produce this condition in Pinus cubensis, presumably when the bark gets soaked by rainwater and breaks off as it shrinks under the drying sun.

The presence of long-dead standing pines with large pieces of fallen wood at their bases has been interpreted as a sign of feeding Ivory-billed Woodpecker by previous expeditions. However, the decayed wood of such trees is weak and the same strong rainstorms appeared to produce this phenomenon also.

Apart from the apparent difficulties in distinguishing Ivory-billed Woodpecker workings from weather-induced scaling, it should be noted that the abundance of scaled trees in 1986, when the birds were still present, was much higher than in 1991 or 1993 (Short and Horne 1986, A.R.E. pers. obs.). Another indication of the species's disappearance from Ojito de Agua is that a part of the forest that was burned in 1990 had not been used for foraging, although the dead trees there were full of ants and wood-boring beetle larvae. Our farcarrying imitated call of the bird never elicited a reaction, and local people who know the area well (e.g. wild boar hunters) have not reported the species in recent years. During the 120 days of fieldwork in which we participated during 1989, 1991 and 1993 no Ivory-billed Woodpeckers were seen or heard.

\section{Ojito de Agua as a reserve}

Even without the Ivory-billed Woodpecker Ojito de Agua is of great importance for biodiversity conservation in Cuba. Of the 84 bird species recorded there, 13 are endemic to Cuba and many of them are still quite numerous. The herpeto- 
fauna is particularly rich, and in recent years four new species of lizard, one snake and two frogs of the genus Eleutherodactylus have been discovered. The latest new frog was found during our 1993 expedition and will be named after the Ivory-billed Woodpecker. More than 110 butterflies are on record, 27 of which are Cuban endemics. Seventy species of spider occur in the area, 10 of these having been discovered during expeditions searching for the Ivory-billed Woodpecker. Of the 200 Cuban endemic plant species present, many are restricted to this region.

Since 1986 Ojito de Agua has been placed under some protection by the Cuban authorities. In view of the unique assemblage of endemic species still living there the area deserves the highest possible grade of protection.

\section{Other mountain areas in eastern Cuba}

Geographers working with satellite photographs at the Instituto de Investigaciones Forestales in Havana have informed us of the few potential sites in the mountains of eastern Cuba at which suitable Ivory-billed Woodpecker habitat might remain. For example, some natural pine forest should remain on the southern slope of Monte Iberia, north of the Jaguaní reserve, although in fact none appeared still to exist and we understood from local residents that it was logged in 1975. The Jaguaní reserve itself holds some $60 \mathrm{~km}^{2}$ of primary hardwood forest, but, as the Ivory-billed Woodpecker is associated in eastern Cuba with pine or mixed forest (Lamb 1957), it is questionable whether it could exist in the pure hardwood stands of the reserve with the nearby pines gone. $B$. Suárez Fernández, who has worked as a warden of Jaguaní for nine years and has a good knowledge of birds, never saw an Ivory-billed Woodpecker in the reserve. When we played the tape of the call of the bird he remembered having heard it once "some years ago" near Ojito de Agua, but never in the Jaguaní reserve. No Ivory-billed Woodpeckers were observed there by a 16-day Cuban expedition in 1987, nor during a short visit by M.L. in 1991.

A visit to the Experimental Station of the Instituto de Investigaciones Forestales in Baracoa revealed that between the Cuchillas de Baràcoa and the Sierra del Purial a reservoir is being constructed and most forest is clear-cut or logged. A report of an Ivory-billed Woodpecker at Pinares de Mayarí in the Sierra de Nipe proved to be false and the forests there are absolutely unsuitable for the species.

In the Sierra Maestra we found a remnant of $18 \mathrm{~km}^{2}$ of almost untouched forest around the Pico la Bayamesa $(1,730 \mathrm{~m})$, with $80 \%$ of the slope area covered by hardwoods and $20 \%$ by large examples of Pinus maestrensis, up to $1.10 \mathrm{~m}$ in diameter at breast height; around the top is cloud-forest. Again, several factors make the presence of Ivory-billed Woodpeckers unlikely. There are no historical reports of the bird, and local residents, even older people, were found to be unfamiliar with it. Nowhere in its range has the species ever been recorded at elevations higher than $800 \mathrm{~m}$, while this forest lies at $1,400-1,730 \mathrm{~m}$. We found no indication of the presence of Ivory-billed Woodpeckers during a seven-day visit.

Since the forest around Pico la Bayamesa is the only intact higher mountain forest in Cuba it should be conserved. Indeed, it already has some protection 
as a war monument because of the fact that revolutionaries fought there. The Institute for Forest Research in Cuba is now urging that it should have the status of nature reserve as well.

\section{Conclusions}

This study has demonstrated that Ojito de Agua and Pico la Bayamesa are the last remnants of Cuba's old-growth mountain forests and should receive full protection because of their importance for the conservation of biodiversity in the country (in Pinar del Río, in the hills of western Cuba, no undisturbed pine forest remains: A.R.E. pers. obs.).

The use of the existence of pine trees with scaled-off bark as proof of the presence of Ivory-billed Woodpeckers seems now to be in doubt. There are many indications that the Ivory-billed Woodpecker has gone from Ojito de Agua and the birds that were seen there in 1986 and 1987 had no extensive old-growth forests in adjacent areas to which they might have moved. Since, by 1991, no evidence for the bird's continued existence in Ojito de Agua could be found, this last-known population probably became extinct in 1989 or 1990 . Within the documented original distribution of the species there now remains no other habitat where unknown populations could survive. A primary forest still stands in the Sierra Maestra, but there are indications that the Ivory-billed Woodpecker has never occurred there. These factors together make it almost certain that the species is extinct in Cuba and thus in the world. It appears that not even a spectacular bird, whose requirements are fully known, which lives in two prosperous countries, and which is threatened by human activity of little economic importance, can be preserved from extinction.

\section{Acknowledgements}

This project was supported by BirdLife International, the Zoological Museum of the University of Amsterdam, Vogelbescherming Nederland and the Instituto de Investigaciones Forestales (IIF) in Cuba. Financial support came from BirdLife International and the Netherlands Foundation for International Nature Protection. Bever Zwerfsport sponsored the equipment. Thanks are due to Huub Huneker, Carlos Peña Rodríguez and Uilder Azhárez Pérez for their company and help with the fieldwork, to the Comision del Medio Ambiente of Holguín Province for their permission to study Ojito de Agua, to the station of IIF in Guisa for its hospitality, to His Excellency the Royal Netherlands Ambassador to Cuba Dr W. A. Dolleman and to Has Keijser, Second Secretary of the Royal Netherlands Embassy in Havana, for their help, to Hubert Kivit for preparing the map, to Geoffrey McMullan for producing the leaflets, and to Jan Wattel for his advice and support throughout the project and for his valuable comments on an earlier version of the manuscript.

\section{References}

Collar, N. J., Gonzaga, L. P., Krabbe, N., Madroño Nieto, A., Naranjo, L. G., Parker, T. A. and Wege, D. C. (1992) Threatened birds of the Americas: the ICBP Red Data Book. Cambridge, U.K.: International Council for Bird Preservation. 
Dennis, J. V. (1948) A last remnant of Ivory-billed Woodpeckers in Cuba. Auk 65: 497507.

Dennis, J. V. (1979) The Ivory-billed Woodpecker Campephilus principalis. Avicult. Mag. 85: 75-84.

Estrada, A. R. and Alayón García, G. (1986a) Reporte de expedición: Búsqueda de Carpintero Real. Volante Migratorio 6: 15.

Estrada, A. R. and Alayón García, G. (1986b) La existencia del Carpintero Real o Pico de Marfil en Cuba, es realidad, no un sueño. Volante Migratorio 7: 25-27.

Jackson, J. A. (1991) Will-o'-the-wisp. Living Bird Q. 10(1): 29-32.

Lamb, G. R. (1957) The Ivory-billed Woodpecker in Cuba. New York: International Committee for Bird Preservation, Pan-American Section (Res. Rep. 1).

Lammertink, J. M. (1992) Search for Ivory-billed Woodpecker in Cuba. Dutch Birding 14: 170-173.

McNeely, J. W. (1992) 1992 Ivory-billed Woodpecker Expedition Report. Unpublished.

Reynard, G. (1988) Bird songs in Cuba. Ithaca, New York: Cornell Laboratory of Ornithology.

Short, L. L. (1985) Last chance for the Ivorybill. Nat. Hist. 94: 66-68.

Short, L. L. and Horne, J. F. M. (1986) The Ivorybill still lives. Nat. Hist. 95: 26, 28.

Short, L. L. and Horne, J. F. M. (1990) The Ivory-billed Woodpecker - the costs of specialization. Pp.93-98 in A. Carlson and G. Aulén, eds. Conservation and management of woodpecker populations. Uppsala: Swedish University of Agricultural Sciences, Department of Wildlife Ecology.

Tanner, J. T. (1942) The Ivory-billed Woodpecker. New York: National Audubon Society (Audubon Res. Rep. 1).

\section{MARTJAN LAMMERTINK}

Instituut voor Systematiek en Populatiebiologie, Universiteit van Amsterdam, P.O. Box 94766, 1090 GT Amsterdam, Netherlands.

ALBERTO R. ESTRADA

Instituto de Investigaciones Forestales, Apartado 5152, La Habana 5, 10500 Cuba. 